\title{
组成确定缓冲溶液中缓冲能力最强的分析
}

\author{
王同为* \\ 新疆科技学院化学化工学院, 新疆 库尔勒 841000
}

摘要: 查阅多种《无机化学》教材及相关参考文献, 发现当缓冲溶液 $\mathrm{pH}=p K_{\mathrm{a}}^{\ominus}$ 时, 对组成确定的缓冲溶液中缓冲能 力最强的解释不够简洁。为此, 在高等教育出版社出版的大连理工大学无机化学教研室编《无机化学》书中缓冲能 力描述的基础上, 借助分布曲线斜率详细解释了当缓冲溶液的 $\mathrm{pH}$ 尽可能接近 $\mathrm{p} K a$ 时, 组成确定的缓冲溶液中缓冲能 力最强。

关键词: 无机化学; 缓冲溶液; 缓冲能力

中图分类号: G64; O6

\section{Analysis of Composition to Determine the Strongest Buffer Capacity in the Buffer Solution}

\section{Tongwei Wang *}

School of Chemistry and Chemical Engineering, Xinjiang University of Science \& Technology, Korla 841000, Xinjiang Uygur Autonomous Region, China.

\begin{abstract}
In a variety of the inorganic chemistry teaching materials and related references that the composition to give the strongest buffer capacity at $\mathrm{pH}=\mathrm{p} K_{\mathrm{a}}^{\ominus}$ is not described concisely. We proposed amendment description for buffer capacity in the book written by teaching and research office of Inorganic Chemistry at Dalian University of Technology. The description is based on the distribution curve slope when buffer solution $\mathrm{pH}$ as close as possible to $\mathrm{p} K_{\mathrm{a}}^{\ominus}$.
\end{abstract}

Key Words: Inorganic chemistry; Buffer solution; Buffer capacity

高等教育出版社出版的由大连理工大学无机化学教研室编写的《无机化学》, 前后经历6版, 是 国内无机化学教科书中非常优秀的一本教材 ${ }^{[1]}$ 。该书结构合理, 教材内容选择和安排与教学科研发 展方向一致, 得到了任课教师和学生的普遍认可。在教学过程中发现, 缓冲溶液的缓冲能力在多本 教材及相关文献中均没有简洁的讲解透彻 ${ }^{[2-4]}$, 故在大连理工大学无机化学教研室编《无机化学》的 基础上设计简化教学过程。

\section{1 问题}

缓冲溶液的缓冲能力属于教材第 5 章第 4 节内容。书中描述为 “在化学分析中定义：使缓冲溶液 的 $\mathrm{pH}$ (表示溶液的酸碱性)改变1.0所需的强酸或强碱的量称为缓冲能力。所以要使缓冲有效, 不仅应 
使缓冲溶液的 $\mathrm{pH}$ 在缓冲范围之内, 而且应尽可能接近 $\mathrm{p} K_{\mathrm{a}}^{\Theta}$ (弱酸解离常数负对数的表示形式)”。学 生对 $\mathrm{pH}$ 尽可能接近 $\mathrm{p} K_{\mathrm{a}}^{\ominus}$ 不易理解, 为此, 以醋酸和醋酸根组成的缓冲溶液为例, 在课堂上进行如下 讲解。

\section{2 讲解过程}

\section{1 绘制醋酸和醋酸根的分布曲线}

分布曲线指的是酸或其共轭碱的分布系数与溶液 $\mathrm{pH}$ 的关系曲线, 分布系数(用 $\delta$ 表示)就是酸或其 共轭碱的摩尔分数(用 $x$ 表示)。

对由定量醋酸和醋酸根所构成的缓冲溶液, 其溶液中存在 $c(\mathrm{HAc})+c\left(\mathrm{Ac}^{-}\right)=$常数, 同时, 还存在 化学平衡: $\mathrm{HAc}(\mathrm{aq})+\mathrm{H}_{2} \mathrm{O}(\mathrm{l}) \rightleftharpoons \mathrm{H}_{3} \mathrm{O}^{+}(\mathrm{aq})+\mathrm{Ac}^{-}(\mathrm{aq}), K_{\mathrm{a}}^{\Theta}(\mathrm{HAc})=\left\{c\left(\mathrm{H}_{3} \mathrm{O}^{+}\right)\right\} \cdot\left\{c\left(\mathrm{Ac}^{-}\right)\right\} /\{c(\mathrm{HAc})\}$ 。

则醋酸的分布系数: $\delta(\mathrm{HAc})=x(\mathrm{HAc})=c(\mathrm{HAc}) /\left[c(\mathrm{HAc})+c\left(\mathrm{Ac}^{-}\right)\right]=1 /\left[1+c\left(\mathrm{Ac}^{-}\right) / c(\mathrm{HAc})\right]$ 。

又 $K_{\mathrm{a}}^{\Theta}(\mathrm{HAc})=\left\{c\left(\mathrm{H}_{3} \mathrm{O}^{+}\right)\right\} \cdot\left\{c\left(\mathrm{Ac}^{-}\right)\right\} /\{c(\mathrm{HAc})\}$, 即: $\left\{c\left(\mathrm{Ac}^{-}\right)\right\} /\{c(\mathrm{HAc})\}=K_{\mathrm{a}}^{\Theta}(\mathrm{HAc}) /\left\{c\left(\mathrm{H}_{3} \mathrm{O}^{+}\right)\right\} 。$

从数量角度分析, 存在 $c\left(\mathrm{Ac}^{-}\right) / c(\mathrm{HAc})=\left\{c\left(\mathrm{Ac}^{-}\right)\right\} /\{c(\mathrm{HAc})\}$ 。

则醋酸的分布系数: $\delta(\mathrm{HAc})=1 /\left[1+c\left(\mathrm{Ac}^{-}\right) / c(\mathrm{HAc})\right]=1 /\left[1+K_{\mathrm{a}}^{\Theta}(\mathrm{HAc}) /\left\{c\left(\mathrm{H}_{3} \mathrm{O}^{+}\right)\right\}\right]$。

又因为 $\mathrm{pH}=-\lg \left\{c\left(\mathrm{H}_{3} \mathrm{O}^{+}\right)\right\}$, 即: $\left\{c\left(\mathrm{H}_{3} \mathrm{O}^{+}\right)\right\}=10^{-\mathrm{pH}}$ 。

所以醋酸的分布系数: $\delta(\mathrm{HAc})=1 /\left[1+K_{\mathrm{a}}^{\Theta}(\mathrm{HAc}) / 10^{-\mathrm{pH}}\right]$ 。

同理, 醋酸根(醋酸的共轭碱)的分布系数: $\delta\left(\mathrm{Ac}^{-}\right)=1 /\left[1+10^{-\mathrm{pH}} / K_{\mathrm{a}}^{\Theta}(\mathrm{HAc})\right]$ 。

由此, 可以绘制出醋酸和其共轭碱的分布系数与溶液 $\mathrm{pH}$ 的关系曲线, 即醋酸和其共轭碱的分布 曲线, 其分布曲线图可参见教材 ${ }^{[1]}$ 。

\section{2 分布曲线斜率意义}

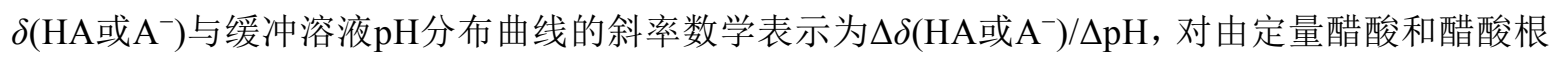
所构成的缓冲溶液, 其溶液中存在 $c(\mathrm{HAc})+c\left(\mathrm{Ac}^{-}\right)=$常数。

在由 $\delta(\mathrm{HAc})=c(\mathrm{HAc}) /\left[c(\mathrm{HAc})+c\left(\mathrm{Ac}^{-}\right)\right]$, 可得出: $\Delta \delta(\mathrm{HAc})=\Delta c(\mathrm{HAc}) /\left[c(\mathrm{HAc})+c\left(\mathrm{Ac}^{-}\right)\right]$。

同理: $\Delta \delta\left(\mathrm{Ac}^{-}\right)=\Delta c\left(\mathrm{Ac}^{-}\right) /\left[c(\mathrm{HAc})+c\left(\mathrm{Ac}^{-}\right)\right]$。

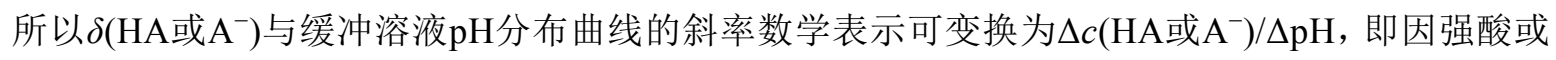
强碱的加入, 最终引起缓冲溶液中HA或A ${ }^{-}$浓度的变化。

结合教材中 “在化学分析中定义: 使缓冲溶液的 $\mathrm{pH}$ 改变1.0所需的强酸或强碱的量称为缓冲能 力。因此, 分布曲线的斜率即代表缓冲溶液的缓冲能力。

对组成确定的缓冲溶液, 分布曲线的斜率数值越大, 缓冲溶液的 $\mathrm{pH}$ 改变1.0所需的强酸或强碱的 量越大, 即说明缓冲溶液的缓冲能力强。因此当斜率取最大值时, 缓冲溶液的缓冲能力最强。

\section{3 以 $\mathrm{Ac}^{-}$为例求算分布曲线斜率的最值}

已知 $\delta\left(\mathrm{Ac}^{-}\right)=1 /\left[1+10^{-\mathrm{pH}} / K_{\mathrm{a}}^{\Theta}(\mathrm{HAc})\right]$,

则 $\left[\delta\left(\mathrm{Ac}^{-}\right)\right]^{\prime}=\left[10^{-\mathrm{pH}} / K_{\mathrm{a}}^{\Theta}(\mathrm{HAc})\right] /\left[1+10^{-\mathrm{pH}} / K_{\mathrm{a}}^{\ominus}(\mathrm{HAc})\right]^{2}$

$$
=1 /\left\{1 /\left[10^{-\mathrm{pH}} / K_{\mathrm{a}}^{\Theta}(\mathrm{HAc})\right]+10^{-\mathrm{pH}} / K_{\mathrm{a}}^{\Theta}(\mathrm{HAc})+2\right\} 。
$$

由基本不等式: $1 /\left[10^{-\mathrm{pH}} / K_{\mathrm{a}}^{\ominus}(\mathrm{HAc})\right]+10^{-\mathrm{pH}} / K_{\mathrm{a}}^{\Theta}(\mathrm{HAc}) \geqq 2$ 。

则: $\left[\delta\left(\mathrm{Ac}^{-}\right)\right]^{\prime}=1 /\left\{1 /\left[10^{-\mathrm{pH}} / K_{\mathrm{a}}^{\Theta}(\mathrm{HAc})\right]+1^{-\mathrm{pH}} / K_{\mathrm{a}}^{\Theta}(\mathrm{HAc})+2\right\} \leqq 1 / 4$ 。

当取最大值时, 存在 $1 /\left[10^{-\mathrm{pH}} / K_{\mathrm{a}}^{\Theta}(\mathrm{HAc})\right]=10^{-\mathrm{pH}} / K_{\mathrm{a}}^{\Theta}(\mathrm{HAc})$, 得 $10^{-\mathrm{pH}}=K_{\mathrm{a}}^{\Theta}(\mathrm{HAc})$, 即 $\mathrm{pH}=\mathrm{p} K_{\mathrm{a}}^{\Theta}(\mathrm{HAc})$ 。

所以, 对组成确定的缓冲溶液, 当溶液 $\mathrm{pH}=\mathrm{p} K_{\mathrm{a}}^{\ominus}(\mathrm{HAc})$ 时, 缓冲溶液的缓冲能力最强。

\section{3 结语}

本文对高等教育出版社出版的大连理工大学无机化学教研室编《无机化学》书中缓冲能力进行 必要的补充, 借助分布曲线斜率详细解释了当缓冲溶液的 $\mathrm{pH}$ 尽可能接近 $\mathrm{p} K_{\mathrm{a}}^{\ominus}$ 时, 组成确定的缓冲溶 液中缓冲能力最强。 
[1] 大连理工大学无机化学教研室编, 孟长功, 主编. 无机化学. 第6版. 北京: 高等教育出版社, 2018: 112-117.

[2] 宋天佑, 程鹏, 徐佳宁, 张丽荣. 无机化学(上册). 第4版. 北京: 高等教育出版社, 2019: 274-277.

[3] 刘又年, 雷家珩, 王林山. 无机化学(上册). 第2版. 北京: 科学出版社, 2013: 102-106.

[4] 陈晓峰, 吴勇, 李顺利, 包建春. 化学教育, 2020, No. 2, 41 . 